\title{
Salinity Tolerance of 12 Turfgrasses in Three Germination Media
}

\author{
Qi Zhang ${ }^{1,4}$, Sheng Wang ${ }^{2}$, and Kevin Rue \\ Department of Plant Sciences, North Dakota State University, NDSU \\ Department 7670, P.O. Box 6050, Fargo, ND 58108
}

Additional index words. agar medium, germination paper, hydroponic, leaf area, $\mathrm{NaCl}$

\begin{abstract}
Salinity tolerance of 12 turfgrasses in four groups, creeping bentgrass (Agrostis stolonifera L.), fescues (Festuca spp.), kentucky bluegrass (Poa pratesis L.), and alkaligrass [Puccinellia distans (Jacq.) Parl.], was evaluated using three germination methods. Seeds were germinated on $1 \%$ agar medium, on germination paper, or in a hydroponic system under salinity levels of $0,5,10,15$, or $20 \mathrm{~g} \cdot \mathbf{L}^{-1} \mathrm{NaCl}$. Germination rate and seedling growth of each grass were determined. Salinity reduced the final germination rate (FGR), daily germination rate (DGR), and seedling leaf area (LA) in all tests. On agar medium, no significant difference in salinity tolerance was observed among the four turf groups; however, 'Turf Blue' kentucky bluegrass with a corn starchbased coating (coated 'Turf Blue') showed a significant higher salinity tolerance than the uncoated one. Using germination paper, creeping bentgrass required the highest salinity level to cause $50 \%$ reduction in FGR followed by alkaligrass, fescues, and kentucky bluegrass. Kentucky bluegrass required the lowest salinity level $\left(9.5 \mathrm{~g} \cdot \mathrm{L}^{-1}\right)$ to reduce DGR by $50 \%$. With the hydroponic system, alkaligrass required a salinity level of 26.3 g. $\mathrm{L}^{-1}$ to reduce FGR by $50 \%$, the highest among the four groups. Alkaligrass showed again the highest salinity tolerance with an average of $12.7 \mathrm{~g} \cdot \mathrm{L}^{-1}$ needed to reduce $L A$ by $\mathbf{5 0 \%}$. Among the grasses, coated 'Turf Blue' kentucky bluegrass, 'Declaration' creeping bentgrass, and 'Fults' alkaligrass showed the highest salinity tolerance when evaluated on agar medium, on germination paper, or in the hydroponic system, respectively. The present study determined the salinity tolerance of 12 turfgrasses at seed germination and early seedling growth stages and showed that the germination method was a factor affecting the evaluation result and it should be considered in a seed germination test of turfgrass for salinity tolerance.
\end{abstract}

High soil salinity is one of the major limitations to plant growth in the northern Great Plains. A survey showed that high levels of soil sodium and salinity were detected in 1,900,000 and 700,000 acres of land in North Dakota, respectively (Seelig, 2000). Soil salinity negatively influences plant growth and development, especially during seed germination and early seedling growth because seeds are more likely to be exposed to saline conditions as a result of evaporation and capillary rise of water near the soil surface (Almansouri et al., 2001). Management practices such as implementation of soil amendment, deep plowing, and leaching and drainage have been used to reduce saline problems. However, the most economically effective method is use of salinitytolerant plants.

\footnotetext{
Received for publication 27 Oct. 2010. Accepted for publication 4 Feb. 2011.

This research was supported in part by Hatch Project ND01540.

We thank Drs. D. Meyer, E. Deckard, and D. Li for their valuable suggestions and comments when we were preparing the manuscript.

${ }^{1}$ Assistant Professor.

${ }^{2}$ Graduate Student.

${ }^{3}$ Research Specialist.

${ }^{4}$ To whom reprint requests should be addressed; e-mail qi.zhang.1@ndsu.edu.
}

Creeping bentgrass (Agrostis stolonifera), fescues (Festuca spp.), and kentucky bluegrass (Poa pratensis) are the most widely used cool-season turfgrasses in the northern Great Plains as a result of good freezing tolerance. However, their relative salt tolerance is ranked moderate [soil electrical conductivity $(\mathrm{EC})=6$ to $10 \mathrm{dS} \cdot \mathrm{m}^{-1}$ ] to sensitive (soil EC less than $3 \mathrm{dS} \cdot \mathrm{m}^{-1}$ ) (Harivandi et al., 1992). As the salinity problem becomes more and more pronounced, alkaligrass (Puccinellia spp.), a native of the prairies in the western United States and Canada, is highly recommended for home lawns under high saline stress. Harivandi et al. (1982) reported that $48 \%$ of Puccinellia spp. seeds germinated after a $15-\mathrm{d}$ exposure to $28.5 \mathrm{dS} \cdot \mathrm{m}^{-1}$ followed by creeping red fescue $[F$. rubra trichophylla (L.) Gaud.] (24\%), perennial ryegrass (Lolium perenne L.) (14\%), and creeping bentgrass $(1 \%)$ but no kentucky bluegrass seed germination was observed. New cultivars are continuously being released in the aforementioned turfgrass species with improved quality such as ' $\mathrm{T}-1$ ' and 'Alpha' creeping bentgrass with high competitiveness over annual bluegrass ( $P$. annua L.) (Brede, 2007), 'Falcon II' and 'Houndog $\mathrm{V}$ ' tall fescue ( $F$. arundinacea Schreb.) with high drought tolerance (Huang, 2001), 'Diva' kentucky bluegrass with high snow molds [Typhula spp. and Macrodochrum nivale (Fr.) Samuels and I.C. Hallett] tolerance
(NTEP, 2006), and 'Fults' and 'Salty' alkaligrass $(P$. distans) with rapid blight (Labyrinthula spp.) tolerance (Peterson et al., 2005). Salinity tolerance of these new cultivars needs to be evaluated.

Various germination media have been used to evaluate relative salinity tolerance in turfgrasses during seed germination. McCarty and Dudeck (1993) and Wang and Zhang (2010) germinated bentgrass (Agrostis spp.) seeds on agar medium with different salinity levels. Dai et al. (2009) also compared salinity tolerance of greens-type $P$. annua seeds on agar medium. Germination rate and seedling growth (blade length and tissue weight) of perennial ryegrass, kentucky bluegrass, and tall fescue cultivars under saline conditions were evaluated in hydroponic systems (Horst and Beadle, 1984; Horst and Dunning, 1989; Horst and Taylor, 1983). Camberato and Martin (2004) compared rough bluegrass ( $P$. trivialis L.) germination rate on germination paper moistened with salt solutions. Similar trends were observed that seed germination and seedling growth are reduced as saline stress severity increases regardless of germination media. However, most experiments were conducted to evaluate salt sensitivity in one species. When comparing relative salinity tolerance among different species or additional cultivars, data were often adopted from other studies, in which different germination media might be used. Very limited information is available on the potential influence of seed germination media on salinity tolerance. Horst and Dunning (1989) compared germination and seedling growth of 48 perennial ryegrass cultivars in salt solutions, in which 'Pennant', 'Palmer', and 'Fiesta' had higher salt tolerance than 'Derby'. In contrast, Dudeck and Peacock (1985) reported that total germination of perennial ryegrass cultivars decreased in the following order: 'Citation II' $\geq$ 'Pennant' $\geq$ 'Palmer' $>$ 'Horizon' $=$ 'Derby' $>$ 'Fiesta' when evaluated on agar medium salinized with sea salt mixture. Such different results might be the result of different seed lots (Camberato and Martin, 2004; McCarty and Dudeck, 1993) or possibly the germination media. The research objectives were to evaluate the salinity tolerance of creeping bentgrass, fescues, kentucky bluegrass, and alkaligrass during seed germination on agar medium, on germination paper, or in a hydroponic system and identify potential differences among the three methods. This research will provide the turf industry useful information for selecting appropriate procedures to compare salinity tolerance in turfgrass species or cultivars at germination and seedling stages.

\section{Materials and Methods}

Seed surface sterilization. Seeds of 12 turfgrasses (Table 1), except coated 'Turf Blue' kentucky bluegrass (grass with a corn starch-based coating), were surface-sterilized according to the method of Wang and Zhang (2010). Briefly, seeds were submerged in $95 \%$ ethanol for $1 \mathrm{~min}$ followed by $2 \%(\mathrm{v} / \mathrm{v})$ sodium hypochlorite solution for $20 \mathrm{~min}$. 
Table 1. Predicted salinity levels $\left(\mathrm{g} \cdot \mathrm{L}^{-1} \mathrm{NaCl}\right)$ causing $50 \%$ reduction in final germination rate and daily germination rate in kentucky bluegrass, fescues, alkaligrass, and creeping bentgrass on agar medium.

\begin{tabular}{|c|c|c|c|c|c|}
\hline$\overline{\text { Group }}$ & PSLF $^{z}$ & PSLD & Grass & PSLF & PSLD \\
\hline \multirow[t]{4}{*}{ Kentucky bluegrass } & $10.3 \mathrm{a}^{\mathrm{x}}$ & $9.9 \mathrm{a}$ & Coated Turf Blue & $15.9 \mathrm{Aa}^{\mathrm{y}, \mathrm{x}}$ & $17.6 \mathrm{Aa}$ \\
\hline & & & Uncoated Turf Blue & $8.2 \mathrm{Bc}$ & 8.1 Bde \\
\hline & & & Diva & $8.3 \mathrm{Bc}$ & $5.7 \mathrm{Bf}$ \\
\hline & & & Bewitched & $8.6 \mathrm{Bc}$ & $8.3 \mathrm{Bc}-\mathrm{e}$ \\
\hline \multirow[t]{4}{*}{ Fescues } & $10.5 \mathrm{a}$ & $9.2 \mathrm{a}$ & Marco Polo sheep fescue & $10.4 \mathrm{Abc}$ & $8.0 \mathrm{Ae}$ \\
\hline & & & Smirna red fescue & $10.4 \mathrm{Abc}$ & $9.5 \mathrm{Ab}-\mathrm{e}$ \\
\hline & & & SR8650 tall fescue & $11.0 \mathrm{Abc}$ & $9.6 \mathrm{Ab}-\mathrm{e}$ \\
\hline & & & Davinci tall fescue & $10.2 \mathrm{Abc}$ & $9.6 \mathrm{Ab}-\mathrm{e}$ \\
\hline \multirow[t]{2}{*}{ Alkaligrass } & $12.5 \mathrm{a}$ & $10.0 \mathrm{a}$ & Salty & $13.0 \mathrm{Aab}$ & $9.8 \mathrm{Ab}-\mathrm{d}$ \\
\hline & & & Fults & $12.0 \mathrm{Ab}$ & $10.1 \mathrm{Abc}$ \\
\hline \multirow[t]{2}{*}{ Creeping bentgrass } & $13.3 \mathrm{a}$ & $10.0 \mathrm{a}$ & Declaration & $15.4 \mathrm{Aa}$ & $10.9 \mathrm{Ab}$ \\
\hline & & & L-93 & $11.2 \mathrm{Bbc}$ & $9.0 \mathrm{Bc}-\mathrm{e}$ \\
\hline
\end{tabular}

${ }^{\mathrm{z} P S L F}=$ the predicted salinity level causing $50 \%$ reduction of final germination rate; PSLD $=$ the predicted salinity level causing $50 \%$ reduction of daily germination rate.

y Upper and lower case letters represent statistical result within each species and among 12 grasses, respectively.

${ }^{\mathrm{x}}$ Means followed by the same letter in each column are not significantly different at $P \leq 0.05$.

Seeds were then rinsed three times with sterile deionized/distilled water $\left(\mathrm{ddH}_{2} \mathrm{O}\right)$ and airdried in a laminar-flow hood.

Seed germination on agar medium. Surface-sterilized seeds of each grass and coated 'Turf Blue' kentucky bluegrass were placed on 1\% agar medium (Sigma-Aldrich Co., St. Louis, MO) supplemented with $0,5,10,15$, or $20 \mathrm{~g} \cdot \mathrm{L}^{-1} \mathrm{NaCl}$ in $100 \times 15-\mathrm{mm}$ petri dishes containing $20 \mathrm{~mL}$ of medium with 36 seeds per plate. The EC of the salt solutions was $0.0,8.4,15.1,21.0$, and $26.1 \mathrm{dS} \cdot \mathrm{m}^{-1}$, respectively, when measured with an EC meter (Model 1054; VWR International LLC, West Chester, PA). The medium was autoclaved at $121^{\circ} \mathrm{C}$ and $103 \mathrm{kPa}$ for $25 \mathrm{~min}$ before being poured into petri dishes. Dishes containing seeds were sealed with parafilm and placed in an incubator (Model 818; Precision Scientific Inc., Chicago, IL) at $25 / 15^{\circ} \mathrm{C}$ (day/night) under fluorescent light $\left(36 \mu \mathrm{mol} \cdot \mathrm{s}^{-1} \cdot \mathrm{m}^{-2}\right)$ with an 8/16-h (light/dark) photoperiod (Association of Official Seed Analysts, 2004).

Seed germination on germination paper. Surface-sterilized seeds of each grass and coated 'Turf Blue' kentucky bluegrass were placed on germination paper (Anchor Paper Company, St. Paul, MN) in $100 \times 15-\mathrm{mm}$ petri dishes with 36 seeds per plate. Before seed plating, the germination paper was moistened with $7 \mathrm{~mL}$ of a $\mathrm{NaCl}$ solution at $0,5,10,15$, or $20 \mathrm{~g} \cdot \mathrm{L}^{-1}$. Dishes were then sealed with parafilm and placed in the same incubator as for the agar test previously described. After 14 and $26 \mathrm{~d}, 2 \mathrm{~mL}$ of the same salt solution for each treatment was added to the plate to keep the paper moist.

Seed germination in hydroponic system. Non-sterilized seeds were germinated in aerated $\mathrm{NaCl}$ solutions at $0,5,10,15$, or $20 \mathrm{~g} \cdot \mathrm{L}^{-1}$ in a growth chamber (Environmental Growth Chambers, Chagrin Falls, OH). Briefly, 12 cells (6-cm diameter) were created on a $30 \times$ $25 \times 2-\mathrm{cm}$ foam plate. Two layers of plastic screen were glued on the bottom of the plate. Thirty-six seeds of each grass were placed in one cell. The plate was floated in the appropriate $\mathrm{NaCl}$ solution. As seeds germinated, roots penetrated through the plastic screen into the salt solution. The salt solution was refreshed every $4 \mathrm{~d}$ with the same concentration. Other conditions were identical to those of the agar medium or germination paper tests.

Data collection and analysis. The number of seeds germinating per plate was recorded three times a week for the agar medium and germination paper tests. Seed germination was defined as an emerged shoot visible under $2 \times$ magnification (McCarty and Dudeck, 1993). Final germination rate and DGR were calculated using FGR $(\%)=100 \times\left[\left(\sum n\right) / 36\right]$ and DGR $(\% / \mathrm{d})=100 \times\left[\sum(n / D)\right] / 36$, respectively, where $n$ was the number of new seeds germinated at each counting and $D$ was the number of days accumulated up to that counting (Wang and Zhang, 2010). In the hydroponic system, only FGR was recorded when the test was ended. Leaves were harvested at the same time and scanned using a photo scanner (V700; Epson America Inc., Long Beach, CA). Leaf area was calculated from the scanned images with WinRhizo (Regent Instruments Inc., Nepean, Canada).

All tests were conducted as a randomized complete block design consisting of three replicates of a 12 (grass) $\times 5$ (salinity level) factorial arrangement. To provide an accurate indication of salinity tolerance, FGR was standardized by setting the value of FGR in control $\left(0 \mathrm{~g} \cdot \mathrm{L}^{-1} \mathrm{NaCl}\right)$ at $100 \%$. Therefore, grass with a higher ratio of FGR under saline condition to FGR in control has greater salinity tolerance (Teolis et al., 2009). Final germination rate and DGR were transformed using arcsine and square root, respectively, to meet the constant variance assumption in the analysis of variance (Wang and Zhang, 2010). All data were subjected to PROC GLM (SAS, 2004). Means were separated with Fisher's protected least significant difference at $P \leq 0.05$. Linear or quadratic regression analysis (PROC GLM) was conducted on nontransformed data to predict salinity levels that cause $50 \%$ reduction in FGR, DGR, and LA within each grass. The salinity tolerance was expressed using the predicted salinity level causing $50 \%$ reduction of FGR (PSLF), the predicted salinity level causing 50\% reduction of DGR (PSLD), and the predicted salinity level causing $50 \%$ reduction of LA (PSLL).

\section{Results and Discussion}

Ranking of salinity tolerance in turfgrasses was similar in transformed and untransformed data in either test (data not shown); thus, data were presented in the original format to avoid difficulty and confusion that might be caused by data transformation.

Effect of salinity on seed germination on agar medium. No significant differences in salt tolerance were observed among four groups when data of PSLF and PSLD within each group were pooled (Table 1). All grasses showed similar salt sensitivity in fescues and alkaligrass. Within kentucky bluegrass, coated 'Turf Blue' was the most salt-tolerant, requiring a $\mathrm{NaCl}$ level of 15.9 and $17.6 \mathrm{~g} \cdot \mathrm{L}^{-1}$ to reduce FGR and DGR by $50 \%$, respectively. The salt tolerance of coated 'Turf Blue' kentucky bluegrass was also the highest of all grasses tested. In creeping bentgrass, the salinity levels causing 50\% reduction in FGR and DGR were 15.4 and $10.9 \mathrm{~g} \cdot \mathrm{L}^{-1}$ in 'Declaration', which were $27.3 \%$ and $17.4 \%$ higher than those in 'L-93' (Table 1). This result is in agreement with the finding of Wang and Zhang (2010), in which they predicted salinity levels of 16.7 and $11.0 \mathrm{~g} \cdot \mathrm{L}^{-1}$ to cause $50 \%$ reduction in FGR and DGR in 'Declaration' and 11.0 and $8.2 \mathrm{~g} \cdot \mathrm{L}^{-1}$ in 'L-93' on agar medium.

Effect of salinity on seed germination on germination paper. In the germination paper experiment, creeping bentgrass showed the highest salt tolerance with a PSLF of 18.7 $\mathrm{g} \cdot \mathrm{L}^{-1}$ followed by alkaligrass, fescues, and kentucky bluegrass (Table 2). Furthermore, 'Declaration' creeping bentgrass was the most salt-tolerant across all grasses used in this test. The predicted salt levels of kentucky bluegrass causing 50\% reduction in both FGR and DGR were significantly lower than other groups, indicating that kentucky bluegrass was very salt-sensitive when germination paper was used. Unlike the agar medium test, coated 'Turf Blue' kentucky bluegrass did not show high salt tolerance compared with other grasses of kentucky bluegrass. 'Bewitched' had the highest PSLD in kentucky bluegrass followed by 'Diva' and coated and uncoated 'Turf Blue' kentucky bluegrass; however, all grasses in the species of kentucky bluegrass showed similar PLSF. Salinity tolerance of the fescues was reduced in the following order: 'Marco Polo' sheep fescue ( $F$. ovina L.) $\geq$ 'SR8650' tall fescue $\geq$ 'Davinci' tall fescue $\geq$ 'Smirna' red fescue. No difference in salt tolerance was noticed in the grasses of alkaligrass.

Effect of salinity on seed germination in a hydroponic system. Final germination rate and LA were used to represent saline tolerance in the hydroponic test. Alkaligrass exhibited the highest salinity tolerance with an average of 26.3 and $12.7 \mathrm{~g} \cdot \mathrm{L}^{-1} \mathrm{NaCl}$ for PSLF and PSLL, respectively (Table 3). Final germination rate was $56 \%$ and $37 \%$ for 'Fults' and 'Salty' alkaligrass, respectively, at the 
highest stress level evaluated in the present study $\left(\mathrm{NaCl}=20 \mathrm{~g} \cdot \mathrm{L}^{-1}\right)$; thus, PSLFs for both alkaligrass cultivars were above $20 \mathrm{~g} \cdot \mathrm{L}^{-1}$ (Table 3). 'Fults' alkaligrass had the highest salt tolerance of all grasses, in which up to 31.7 and $13.1 \mathrm{~g} \cdot \mathrm{L}^{-1} \mathrm{NaCl}$ were needed to reduce the FGR and LA by $50 \%$. The differences in salt tolerance among kentucky bluegrass, fescues, and creeping bentgrass were not significant. Moreover, no significant difference in salt tolerance occurred among grasses in these three groups, except that 'Marco Polo' sheep fescue required a lower salinity level to reduce LA by $50 \%$ than the other fescues (Table 3).

Responsiveness of final germination rate, daily germination rate, and leaf area to salt stress. Final germination rate, DGR, and LA decreased as the salinity level increased in all media when data were pooled across grasses (Table 4). The decrease of FGR was slower than that of DGR or LA as salinity level increased. For example, FGR was either unaffected or reduced less than $5 \%$ when the salinity level increased from 0 to $5 \mathrm{~g} \cdot \mathrm{L}^{-1}$. In contrast, DGR was reduced by $15 \%$ and $20 \%$ when germinated on germination paper and on agar medium, respectively, as the salinity condition increased to the same level. Leaf area was reduced to $93.7 \mathrm{~cm}^{2}$ at $5 \mathrm{~g} \cdot \mathrm{L}^{-1} \mathrm{NaCl}$, $39 \%$ lower than that at $0 \mathrm{~g} \cdot \mathrm{L}^{-1}$. Furthermore, PSLD and PSLL in all grasses were lower than PSLF in all tests, except that PSLD of coated 'Turf Blue' kentucky bluegrass was $17.6 \mathrm{~g} \cdot \mathrm{L}^{-1}, 10.7 \%$ higher than PSLF on the agar medium (Table 1). Thus, DGR and LA seemed more sensitive to salt stress than FGR. Similar findings were reported by Camberato and Martin (2004), Marcar (1987), and Wang and Zhang (2010).

The coating of coated 'Turf Blue' kentucky bluegrass is a corn starch-based product that helps hold water. In the present study, FGR of coated 'Turf Blue' kentucky bluegrass would be reduced by $50 \%$ at a salt level of $15.9 \mathrm{~g} \cdot \mathrm{L}^{-1}$ on agar medium, $47.4 \%$ higher than that of uncoated 'Turf Blue', 'Diva', and 'Bewitched' kentucky bluegrass (Table 1). Furthermore, coated 'Turf Blue' kentucky bluegrass had the highest DGR in kentucky bluegrass, even under the highest saline condition $\left(20 \mathrm{~g} \cdot \mathrm{L}^{-1}\right)$ on agar medium (Fig. 1). Such a trend was not observed when seeds were germinated on the germination paper or in the hydroponic system (Tables 2 and 3; Fig. 1). It may be that the coating is easily washed off by salt solutions on the germination paper and in the hydroponic tests and thereby losing its function of holding water. However, the gelling agent agar not only provides a support site for seed germination, but also is a buffer system that can buffer sudden changes in temperature, moisture, and $\mathrm{pH}$. This function of the agar medium is similar to the soil system; therefore, coating seeds may be an effective method to increase salinity tolerance of seeds during their germination in the soil.

Camberato and Martin (2004) suggested that seeds might be exposed to higher saline levels as a result of evaporation as the

Table 2. Predicted salinity levels $\left(\mathrm{g} \cdot \mathrm{L}^{-1} \mathrm{NaCl}\right)$ causing $50 \%$ reduction in final germination rate and daily germination rate in kentucky bluegrass, fescues, alkaligrass, and creeping bentgrass on germination paper.

\begin{tabular}{|c|c|c|c|c|c|}
\hline Group & PSLF $^{z}$ & PSLD & Grass & $\begin{array}{l}\text { PSLF } \\
\end{array}$ & PSLD \\
\hline \multirow[t]{4}{*}{ Kentucky bluegrass } & $10.4 \mathrm{c}^{\mathrm{x}}$ & $9.5 \mathrm{~b}$ & Coated Turf Blue & $10.0 \mathrm{Aef}^{\mathrm{y}, \mathrm{x}}$ & $9.2 \mathrm{BCd}$ \\
\hline & & & Uncoated Turf Blue & $9.9 \mathrm{Af}$ & $9.2 \mathrm{Cd}$ \\
\hline & & & Diva & $10.8 \mathrm{Ad}-\mathrm{f}$ & $9.8 \mathrm{ABcd}$ \\
\hline & & & Bewitched & $11.1 \mathrm{Ad}-\mathrm{f}$ & 9.8 Acd \\
\hline \multirow{4}{*}{ Fescues } & $15.2 \mathrm{~b}$ & $11.1 \mathrm{a}$ & Marco Polo sheep fescue & 19.2 Aab & $12.0 \mathrm{Abc}$ \\
\hline & & & Smirna red fescue & $11.6 \mathrm{Cd}-\mathrm{f}$ & $9.8 \mathrm{Ccd}$ \\
\hline & & & SR8650 tall fescue & 16.0 ABbc & $11.9 \mathrm{ABbc}$ \\
\hline & & & Davinci tall fescue & $14.1 \mathrm{BCc}-\mathrm{e}$ & $10.6 \mathrm{BCb}-\mathrm{d}$ \\
\hline \multirow[t]{2}{*}{ Alkaligrass } & $17.0 \mathrm{ab}$ & $12.1 \mathrm{a}$ & Salty & $16.3 \mathrm{Abc}$ & $11.3 \mathrm{Ab}-\mathrm{d}$ \\
\hline & & & Fults & $17.8 \mathrm{Abc}$ & 13.0 Aab \\
\hline \multirow[t]{2}{*}{ Creeping bentgrass } & $18.7 \mathrm{a}$ & $12.3 \mathrm{a}$ & Declaration & $23.0 \mathrm{Aa}$ & 14.7 Aa \\
\hline & & & L-93 & $14.4 \mathrm{Bcd}$ & $9.9 \mathrm{Bcd}$ \\
\hline
\end{tabular}

${ }^{2} \mathrm{PSLF}=$ the predicted salinity level causing $50 \%$ reduction of final germination rate; PSLD $=$ the predicted salinity level causing $50 \%$ reduction of daily germination rate.

${ }^{y}$ Upper and lower case letters represent statistical result within each species and among 12 grasses, respectively.

${ }^{x}$ Means followed by the same letter in each column are not significantly different at $P \leq 0.05$.

Table 3. Predicted salinity levels $\left(\mathrm{g} \cdot \mathrm{L}^{-1} \mathrm{NaCl}\right)$ causing $50 \%$ reduction in final germination rate and leaf area in kentucky bluegrass, fescues, alkaligrass, and creeping bentgrass in a hydroponic system.

\begin{tabular}{lcclcc}
\hline Group & PSLF $^{\mathrm{z}}$ & PSLL & \multicolumn{1}{c}{ Grass } & PSLF & PSLL \\
\hline Kentucky bluegrass & $10.0 \mathrm{~b}^{\mathrm{x}}$ & $7.0 \mathrm{~b}$ & Coated Turf Blue & $10.0 \mathrm{Abc} \mathrm{y}, \mathrm{x}$ & $7.7 \mathrm{Acd}$ \\
& & & Uncoated Turf Blue & $9.9 \mathrm{Abc}$ & $7.9 \mathrm{Acd}$ \\
& & & Diva & $9.5 \mathrm{Ac}$ & $5.8 \mathrm{Ad}$ \\
& & & Bewitched & $10.8 \mathrm{Abc}$ & $6.7 \mathrm{Acd}$ \\
Fescues & \multirow{2}{*}{$13.3 \mathrm{~b}$} & \multirow{2}{*}{$8.9 \mathrm{~b}$} & Marco polo sheep fescue & $9.6 \mathrm{Ac}$ & $5.7 \mathrm{Bd}$ \\
& & & Smirna red fescue & $15.2 \mathrm{Abc}$ & $9.7 \mathrm{Aa}-\mathrm{d}$ \\
& & & SR8650 tall fescue & $14.7 \mathrm{Abc}$ & $9.4 \mathrm{Aa}-\mathrm{d}$ \\
& & & Davinci tall fescue & $13.8 \mathrm{Abc}$ & $10.8 \mathrm{Aa}-\mathrm{c}$ \\
Alkaligrass & \multirow{2}{*}{$26.3 \mathrm{a}$} & \multirow{2}{*}{$12.7 \mathrm{a}$} & Salty & $20.9 \mathrm{Aab}$ & $12.2 \mathrm{Aab}$ \\
& & & Fults & $31.7 \mathrm{Aa}$ & $13.1 \mathrm{Aa}$ \\
Creeping bentgrass & \multirow{2}{*}{$11.2 \mathrm{~b}$} & \multirow{2}{*}{$9.6 \mathrm{~b}$} & Declaration & $12.6 \mathrm{Abc}$ & $10.4 \mathrm{Aa}-\mathrm{c}$ \\
& & & L-93 & $9.8 \mathrm{Abc}$ & $8.9 \mathrm{Ab}-\mathrm{d}$ \\
\hline
\end{tabular}

${ }^{\mathrm{z} P S L F}=$ the predicted salinity level causing $50 \%$ reduction of final germination rate; $\mathrm{PSLL}=$ the predicted salinity level causing $50 \%$ reduction of leaf area.

${ }^{y}$ Upper and lower case letters represent statistical result within each species and among 12 grasses, respectively.

${ }^{\mathrm{x}}$ Means followed by the same letter in each column are not significantly different at $P \leq 0.05$.

Table 4. Effect of salinity on final germination rate (FGR, \%), daily germination rate (DGR, \%/d), and leaf area $\left(\mathrm{LA}, \mathrm{cm}^{2}\right)$ in three germination media across grasses.

\begin{tabular}{|c|c|c|c|c|c|c|}
\hline \multirow{2}{*}{$\begin{array}{l}\mathrm{NaCl} \\
\left(\mathrm{g} \cdot \mathrm{L}^{-1}\right)\end{array}$} & \multicolumn{2}{|c|}{ Agar medium } & \multicolumn{2}{|c|}{ Germination paper } & \multicolumn{2}{|c|}{ Hydroponic system } \\
\hline & $\overline{\text { FGR (\%) }}$ & DGR $(\% / \mathrm{d})$ & $\overline{\text { FGR (\%) }}$ & DGR $(\% / \mathrm{d})$ & $\overline{\text { FGR }(\%)}$ & LA $\left(\mathrm{cm}^{2}\right.$ \\
\hline 0 & $100.0 \mathrm{a}^{\mathrm{z}}$ & $12.4 \mathrm{a}$ & $100.0 \mathrm{a}$ & $12.0 \mathrm{a}$ & $100.0 \mathrm{a}$ & $153.0 \mathrm{a}$ \\
\hline 5 & $96.5 \mathrm{a}$ & $10.0 \mathrm{~b}$ & $101.7 \mathrm{a}$ & $10.2 \mathrm{~b}$ & $98.3 \mathrm{~b}$ & $93.7 \mathrm{~b}$ \\
\hline 10 & $64.7 \mathrm{~b}$ & $5.6 \mathrm{c}$ & $88.5 \mathrm{~b}$ & $7.0 \mathrm{c}$ & $68.2 \mathrm{c}$ & $49.2 \mathrm{c}$ \\
\hline 15 & $27.4 \mathrm{c}$ & $2.1 \mathrm{~d}$ & $51.8 \mathrm{c}$ & $3.3 \mathrm{~d}$ & $35.8 \mathrm{~d}$ & $19.4 \mathrm{~d}$ \\
\hline 20 & $6.8 \mathrm{~d}$ & $0.7 \mathrm{e}$ & $18.5 \mathrm{~d}$ & $1.0 \mathrm{e}$ & $14.2 \mathrm{e}$ & $4.3 \mathrm{e}$ \\
\hline
\end{tabular}

${ }^{2}$ Means followed by the same letter in each column are not significantly different at $P \leq 0.05$.

experiment progresses when they were germinated on germination paper. In the present study, dew accumulation was observed inside the petri dishes; thus, saline levels were increased. It is unclear about the extent of salinity increase during the study. However, because all grasses were exposed to identical conditions, relative salinity tolerance in the grasses was still comparable using germination paper. Moreover, PSLF and PSLD from the germination paper test were in the close range with that from the other two methods.

The three germination methods showed similar trends in evaluating salinity tolerance of turfgrasses that salinity reduces germination and early seedling growth. A few grasses were consistently ranked either high or low in salinity tolerance across the three germination methods. For example, 'Fults' and 'Salty' alkaligrass and creeping bentgrass showed high salinity tolerance, whereas 'Diva', 'Bewitched', and uncoated 'Turf Blue' kentucky bluegrass had low salt tolerance. However, some exceptions were also observed such as variation of salt tolerance of coated 'Turf Blue' kentucky bluegrass. Similarly, 'Declaration' creeping bentgrass showed superior salt tolerance on the agar medium and germination paper tests but moderate tolerance in the hydroponic test. 'Marco Polo' sheep fescue was ranked salt-tolerant in the germination paper test but medium on the agar medium test and sensitive in the hydroponic test. It has been reported that different plants 


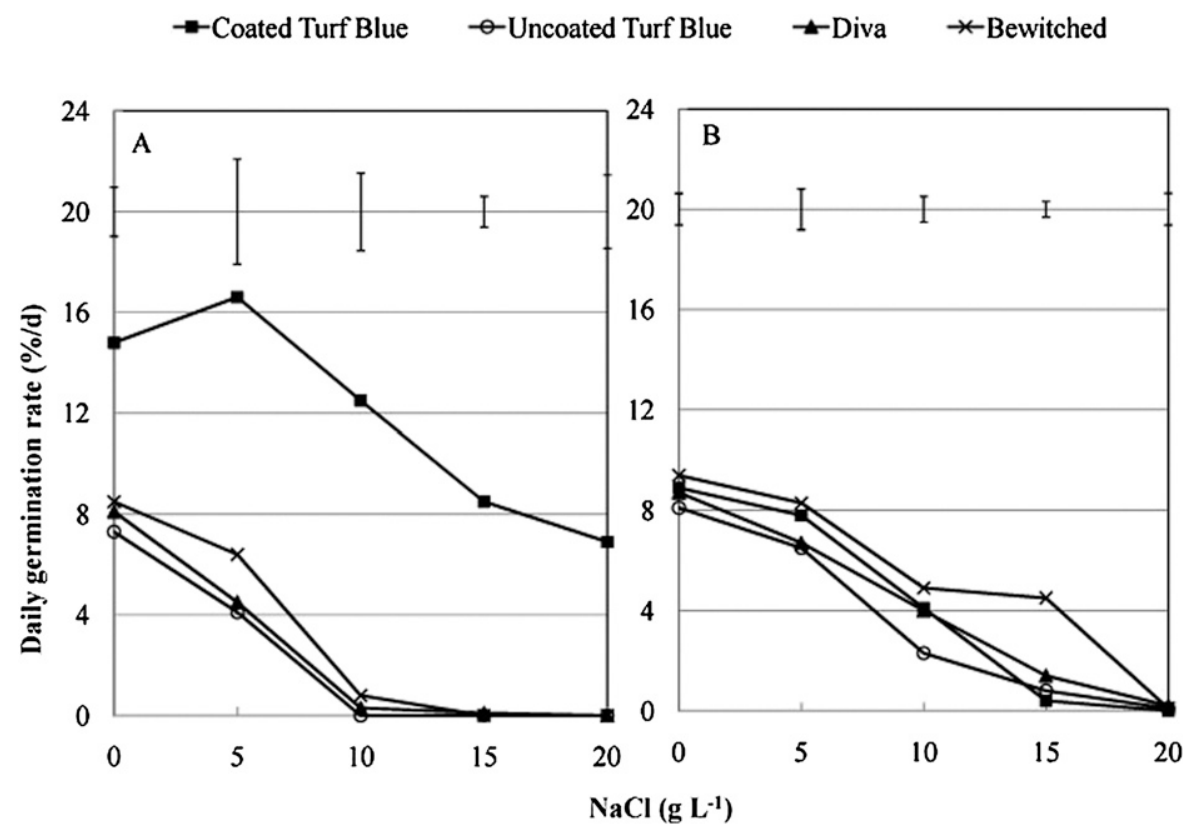

Fig. 1. Effect of salinity on daily germination rate of four Kentucky bluegrass cultivars on agar medium (A) or germination paper (B). Vertical bars represent least significant difference at $P \leq 0.05$.

respond to salt stress differently. Some plants are only affected by the osmotic stress induced by salinity, whereas other plants are influenced by both imbalance of osmotic potential and ion toxicity in the salt solution (Dodd and Donovan, 1999). 'Marco Polo' sheep fescue and 'Declaration' creeping bentgrass might be such genotypes that are very sensitive to ionic toxicity, therefore showing reduced salinity tolerance in the hydroponic system compared with the other methods. Overall, this study shows that the seed germination method should be taken into consideration when evaluating salinity tolerance in turfgrass.

Agar medium, germination paper, and hydroponic system are commonly used as germination media for a quick screening of salinity tolerance in plants under a controlled environment. Autoclave facility and trained personnel are needed for medium preparation and seed sterilization when agar medium and germination paper methods are used. Furthermore, some seeds such as buffalograss are very difficult to sterilize; therefore, contamination is always a concern. Salt accumulation on the
Camberato, J.J. and S.B. Martin. 2004. Salinity slows germination of rough bluegrass. HortScience 39:394-397.

Dai, J., D.R. Huff, and M.J. Schlossberg. 2009. Salinity effects on seed germination and vegetative growth of green-type Poa annua relative to other cool-season turfgrass species. Crop Sci. 49:696-703.

Dodd, G.L. and L.A. Donovan. 1999. Water potential and ionic effects on germination and seedling growth of two cold desert shrubs. Amer. J. Bot. 86:1146-1153.

Dudeck, A.E. and C.H. Peacock. 1985. Salinity effects on perennial ryegrass germination. HortScience 20:268-269.

Harivandi, M.A., J.D. Butler, and P.M. Soltanpour. 1982. Salt influence on germination and seedling survival of six cool season turfgrass species. Commun. Soil Sci. Plant Anal. 13:519-529.

Harivandi, M.A., J.D. Butler, and L. Wu. 1992. Salinity and turfgrass culture, p. 208-229. In: Waddington, D.V., R.N. Carrow, and R.C. Shearman (eds.). Turfgrass. ASA-CSSA-SSSA, Madison, WI.

Horst, G.L. and N.B. Beadle. 1984. Salinity affects germination and growth of tall fescue cultivars. J. Amer. Soc. Hort. Sci. 109:419-422.

Horst, G.L. and N.B. Dunning. 1989. Germination and seedling growth of perennial ryegrass in soluble salts. J. Amer. Soc. Hort. Sci. 114:338-342.

Horst, G.L. and R.M. Taylor. 1983. Germination and initial growth of Kentucky bluegrass in soluble salts. Agron. J. 75:679-681.

germination paper may change the salinity stress level constantly. For the hydroponic method, more management (i.e., changing solutions) is needed. Agar medium functions more similar to a soil system, yet hydroponic system has the least limitation for seedling growth. All three methods require certain facilities (transfer hood and incubator), equipment (autoclave and aeration pump), and adequate space. Researchers and practitioners have to choose a proper germination method based on their facility and purpose with understanding of the influence of different germination methods on salinity tolerance.

\section{Literature Cited}

Almansouri, M., J.M. Kinet, and S. Lutts. 2001. Effect of salt and osmotic stresses on germination in durum wheat (Triticum durum Desf.). Plant Soil 231:243-254.

Association of Official Seed Analysts. 2004. Rules for testing seeds. Association of Official Seed Analysts, Ithaca, NY.

Brede, A.D. 2007. 'Alpha' and 'T-1' creeping bentgrass, new cultivars for golf. HortScience 42:1301-1302.

Huang, B. 2001. Nutrient accumulation and associated root characteristics in response to drought stress in tall fescue cultivars. HortScience 36: 148-152.

Marcar, N.E. 1987. Salt tolerance in the genus Lolium (ryegrass) during germination and growth. Aust. J. Agr. Res. 38:297-307.

McCarty, L.B. and A.E. Dudeck. 1993. Salinity effects on bentgrass germination. HortScience 28:15-17.

NTEP. 2006. 2000 National kentucky bluegrass test. Final report NTEP No. 06-11.

Peterson, P.D., S.B. Martin, and J.J. Camberato. 2005. Tolerance of cool-season turfgrasses to rapid blight disease. Applied Turfgrass Sci. doi:10.1094/ATS-2005-0328-01-RS.

SAS. 2004. SAS 9.1.2 qualification tools user's guide. SAS Institute Inc., Cary, NC.

Seelig, B.D. 2000. Salinity and sodicity in North Dakota Soils. 7 Feb. 2011. <http://www.ag. ndsu.edu/pubs/plantsci/soilfert/eb57-1.htm>.

Teolis, I., W. Liu, and E.B. Peffley. 2009. Salinity effects on seed germination and plant growth of guar. Crop Sci. 49:637-642.

Wang, S. and Q. Zhang. 2010. Responses of creeping bentgrass to salt stress during in vitro germination. HortScience 45:1747-1750. 